\title{
Implementasi Kebijakan Program Pensiun Dini Di PT. Telkom Regional 1 Sumatera
}

\section{Implementation of Early Pension Program Policy in PT. Telkom Regional 1 Sumatera}

\author{
Rizka Dwi Putri*, Abdul Kadir \& Irwan Nasution \\ Program Studi Administrasi Publik, Fakultas Ilmu Sosial Dan Politik, Universitas Medan Area, \\ Indonesia

\section{Abstrak}

Tujuan dari penelitian ini untuk mengetahui Implementasi Kebijakan Program Pensiun Dini Di PT Telkom Regional 1 Sumatera. Jenis penelitian yang digunakan penelitian kualititatif, teknik pengumpulan dengan triangulasi (gabungan), analisis data bersifat induktif kualitatif. Hasil penelitian yang diperoleh peneliti bahwa Implementasi Kebijakan Program Pensiun Dini Di PT. Telkom Regional 1 Sumatera melalui kegiatan yang dilakukan dalam program pensiun dini diantaranya sosialisasi, pendaftaran, seleksi, konseling dan pembekalan, dan tahapannya di bagi atas dua bagian dan dalam menilai keberhasilan implementasi dari model George Edward III terdapat 4 (empat) variabel yang mempengaruhi keberhasilan atau kegagalan implementasi kebijakan antara lain yaitu faktor komunikasi, sumber daya, disposisi dan struktur birokrasi. Keempat variabel tersebut saling berhubungan satu sama lain. Berdasarkan hasil penelitian dan pembahasan, peneliti dapat menyimpulkan bahwa Implementasi Kebijakan Program Pensiun Dini Di PT. Telkom belum maksimal dalam menjalankan program pensiun dini, terlihat dari tahap-tahap yang dilalui dalam implementasi kebijakan program pensiun dini di PT. Telkom.

Kata Kunci: Implementasi Kebijakan, Program, Pensiun Dini

\begin{abstract}
The purpose of this study was to determine the implementation of the early retirement program policy at PT Telkom Regional 1 Sumatra. This type of research is qualitative research, triangulation (combined) collection techniques, qualitative inductive data analysis and research results. Research results obtained by researchers that the Implementation of Early Pension Program Policies at PT. Telkom Regional 1 Sumatra through Activities carried out in the early retirement program including socialization, registration, selection, counseling and briefing, and the stages are divided into two parts and in assessing the successful implementation of the George Edward III model there are 4 (four) variables that affect the success or failure of policy implementation, among others, are the factors of communication, resources, disposition and bureaucratic structure. The four variables are interconnected with each other. Based on the results of research and discussion, researchers can conclude that the Implementation of Early Pension Program Policies at PT. Telkom has not been maximized in carrying out an early retirement program, This Can Be Seen From The Stages Passed In Implementing Early Pension Program Policies at PT. Telkom. The conclusion from this study that researchers can conclude that the Implementation of Early Pension Program Policies at PT. Telkom has not been maximized in running an early retirement program.
\end{abstract}

Keywords: Policy Implementation, Programs, Early Retirement

How to Cite: Dwi Putri, Rizka. Kadir, Abdul. \& Nasution, Irwan. (2019) Implementasi Kebijakan Program Pensiun Dini Di PT. Telkom Regional 1 Sumatera. Jurnal Ilmu Pemerintahan, Administrasi Publik dan Ilmu Komunikasi (JIPIKOM), 1(2) 2019: 130-136,

*E-mail: rizkadwiputri@gmail.com

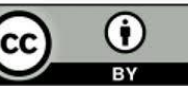




\section{PENDAHULUAN}

Tenaga kerja merupakan aset perusahaan yang sangat berharga karena mereka memberikan kontribusinya demi pencapaian tujuan perusahaan. Oleh karena itu sudah selayaknya tenaga kerja mendapatkan perhatian dari perusahaan, dimana perhatian yang paling utama adalah masa depan tenaga kerja sendiri. Perhatian tersebut sangat dibutuhkan ketika mereka memasuki usia lanjut di mana mereka sudah tidak produktif lagi atau dapat dikatakan mereka tidak dapat lagi mengandalkan kekuatan fisik atau kegiatan berfikirnya untuk memperoleh penghasilan.

Dalam hal meningkatkan kesejahteraan para karyawan salah satu yang dilakukan perusahaan yaitu melaksanakan program pensiun seperti yang disebutkan dalam UU No. 13 Tahun 2003 Tentang Ketenagakerjaan, bahwa diperlukan pembangunan ketenagakerjaan untuk meningkatkan kualitas tenaga kerja serta peningkatan perlindungan tenaga kerja dan keluarganya sesuai dengan harkat dan martabat kemanusiaan, sedangkan dalam penyelenggaraan program pensiun sesuai dengan fungsi UU No. 11 Tahun 1992 Tentang Dana Pensiun. Oleh karena itu, merupakan suatu komitmen bagi perusahaan untuk mengupayakan suatu sarana yang nantinya diharapkan dapat membantu tenaga kerja dalam menjaga kesinambungan penghasilannya dimasa depan (Atika \& Tarigan, 2014).

Telkom sebagai salah satu BUMN besar di Indonesia turut melaksanakan program pensiun dini. Pensiun yang terjadi untuk melakukan restrukturisasi pada organisasi dengan memberikan status pensiun pada karyawan yang seharusnya belum layak pensiun dan diberikan pesangon sesuai dengan masa kerja. Kebijakan suatu perusahaan mengadakan program pensiun dini bertujuan untuk mengurangi jumlah karyawan yang tidak produktif lagi, sehingga pekerjaan yang biasa ditangani dapat diselesaikan oleh karyawan yang lain. Pensiun Dini dapat dilihat dari dua sisi, dari keinginan pekerja itu sendiri atau dari kebijakan perusahaan.

Fenomena yang aktual tentang adanya pensiun dini di tengah-tengah masyarakat yang menjadi perbincangan hangat. Pensiun dini makin marak diperbincangkan di masyarakat karena ada sebagian orang yang bertanya- tanya mengapa karyawan dengan umur yang masih relatif muda atau masih produktif bisa pensiun dini. Dari sebagian fenomena yang ditemukan terdapat beberapa alasan perusahaan memberhentikan atau memensiunkan karyawannya. Hal tersebut dilakukan karena alasan tidak dapat menampung dan melebihi target yang telah ditentukan oleh Pemerintah. Dengan kondisi perekonomian Indonesia yang saat ini sedang tidak stabil, berimbas juga pada sebagian besar perusahaan-perusahaan yang ada di Indonesia saat ini. Pensiun dini itu sendiri ada dua kategori yaitu pensiun dini yang dilakukan atas keinginan sendiri dan pensiun dini yang dilakukan oleh perusahaan.

Dalam mengelolah kebijakan dan pelaksanaan pensiun dini, perusahaan harus berhati-hati dalam mengimplementasikannya, karena apabila perusahaan tidak dengan semestinya menjalankan kebijakan pensiun dini, maka perusahaan memperoleh masalah yang cukup besar. Berdasarkan uraian di atas maka tujuan dari penelitian ini untuk mengetahui implementasi kebijakan program pensiun dini Di PT Telkom Regional 1 Sumatera.

Implementasi kebijakan merupakan faktor yang paling penting bagi keberhasilan sebuah kebijakan. Tanpa diimplementasikan kebijakan publik hanya akan menjadi dokumentasi belaka. Hal lain yang penting dalam implementasi kebijakan adalah tidak semua kebijakan yang diambil dan disahkan oleh pemerintah dengan sendirinya akan dapat dilaksanakan sesuai dengan tujuan kebijakan itu. Menurut Patton dan Sawicki (Tangkilisan, 2003) bahwa implementasi berkaitan dengan berbagai kegiatan yang 
Rizka Dwi Putri, Abdul Kadir \& Irwan Nasution, Implementasi Kebijakan Program Pensiun Dini Di PT.

diarahkan untuk merelesasikan program, dimana posisi ini eksekutif mengatur cara untuk mengorganisir, menginterprestasikan dan menerapkan kebijakan yang diseleksi.

Manajemen sumber daya manusia secara umum memiliki peranan dalam perusahaan untuk memastikan bahwa organisasi mampu mencapai keberhasilan melalui orang lain. Sumber daya manusia atau karyawan bagi sebuah perusahan berupa keterlibatan mereka dalam sebuah perencanaan, sistem, proses dan tujuan yang ingin dicapai oleh perusahaan. Menurut Hasibuan (2000) pensiun adalah pemberhentian karyawan atas keinginan perusahaan, berdasarkan Undang-Undang ataupun keinginan karyawan sendiri. Keinginan perusahaan mempensiunkan karyawan adalah karena produktivitas kerjanya rendah sebagai akibat usia lanjut, cacat fisik, kecelakaan dalam melaksanakan pekerjaan, dan sebagainya. Pensiun merupakan waktu disaat seorang karyawan berhenti bekerja pada sebuah perusahaan karena alasan tertentu.

\section{METODE PENELITIAN}

Jenis penelitian ini adalah penelitian kualititatif, menurut Sugiyono, (2015) mengemukakan bahwa penelitian kualitatif adalah metode penelitian yang digunakan untuk meneliti pada kondisi objek yang alamiah (sebagai lawannya adalah eksperimen) dimana peneliti sebagai instrument kunci. Pengambilan sampel sumber data dilakukan secara pusposive dan snowball. Teknik pengumplan dengan triangulasi (gabungan), analisis data bersifat induktif kualitatif dan hasil penelitian kualitatif lebih menekankan makna dari pada generalisasi.

Tempat diadakannya penelitian ini adalah PT Telkom Regional 1 yang berada di JL. Prof. DR. HM Yamin Sh No.2, Kesawan, Medan. Sugiyono (2015) teknik pengumpulan data merupakan langkah yang paling utama dalam penelitian, karena tujuan utama dari penelitian adalah mendapatkan data. Dalam penelitian ini, untuk memperoleh data dan informasi atau keterangan- keterangan yang diperlukan penulis menggunakan metode sebagai berikut: (1) Wawancara, menurut (Sugiyono, 2015) wawancara digunakan sebagai teknik pengumpulan data apabila peneliti ingin melakukan studi pendahuluan untuk menemukan permasalahan yang harus diteliti tetapi juga apabila peneliti ingin mengetahui hal-hal dari responden yang lebih mendalam; (2) Observasi, menurut Nasution dalam Sugiyono (2015) observasi adalah dasar semua ilmu pengetahuan, para ilmuan hanya dapat bekerja berdasarkan data, yaitu fakta mengenai dunia kenyataan yang diperoleh oleh observasi; (3) Dokumentasi, masih menurut Sugiono (2015) dokumen merupakan catatan peristiwa yang sudah berlalu. Dokumen bias berbentuk tulisan, gambar atau karya monumental dari seseorang.

Menurut Miles dan Huberman dalam Sugiyono (2015) teknis analisis data yang digunakan meliputi (1) reduksi data, data yang diperoleh dilapangan peneliti dituangkan dalam uraian atau laporan yang lengkap dan terperinci; (2) penyajian data, menggambarkan secara keseluruhan data peneliti; (3) verifikasi data atau penarikan kesimpulan, penarikan kesimpulan awal yang dikemukakan masih bersifat sementara dan akan merubah bila tidak ditemukan bukti-bukti yang kuat mendukung pada tahap pengumpulan data berikutnya. Tetapi apabila kesimpulan yang dikemukakan pada awalnya didukung oleh bukti-bukti yang valid dan konsisten saat peneliti kembali ke lapangan mengumpulkan data, maka kesimpulan yang dikemukakan merupakan kesimpulan yang kredibel.

\section{HASIL DAN PEMBAHASAN}

Menurut Harsono (2002) implementasi merupakan suatu proses untuk melaksanakan kebijakan menjadi tindakan kebijakan dari politik kedalam administrasi. Pengembangan 
kebijakan dalam rangka penyempurnaan suatu program. Keberhasilan implementasi dari model George Edward III (Widodo, 2010) terdapat 4 (empat) variabel yang mempengaruhi keberhasilan atau kegagalan implementasi kebijakan antara lain yaitu faktor komunikasi, sumber daya, disposisi dan struktur birokrasi. Keempat variabel tersebut saling berhubungan satu sama lain.

Komunikasi (communication). Dalam implementasi kebijakan memerlukan komunikasi suatu program yang baik bagi para pelaksana. Hal ini menyangkut dari cara penyampaian informasi, kejelasan informasi dan konsistensi informasi yang disampaikan agar mencapai tujuan. Faktor komunikasi ini menunjukkan perasaan sebagai acuran agar pelaksana kebijakan mengetahui persis apa yang akan mereka kerjakan. Ini berarti bahwa komunikasi juga dapat dinyatakan dengan perintah dari atas terhadap pelaksana-pelaksana kebijakan sehingga penerapan kebijakan tidak keluar dari sasaran yang dikehendaki. Dengan demikian komunikasi tersebut harus dinyatakan dengan jelas, tepat dan konsisten.

Sumber Daya (Resourches). Dilihat dari sumber daya meliputi empat komponen yaitu sumber daya manusia (staff), fasilitas (facility) yang dibutuhkan dalam pelaksanaan, wewenang (authorit) yang cukup guna melaksanakan tugas atau bertanggung jawab dan informasi (information) yang dibutuhkan guna pengambilan keputusan.

Disposisi. Disposisi atau sikap pelaksana merupakan komitmennya implementor pelaksana terhadap program. Jadi sikap pelaksana terhadap program tersebut baik maka akan berhasil sesuai tujuan.

Struktur Birokrasi (Bureaucratic Strukture). Struktur organisasi adalah termasuk tata aliran kerja birokrasi yang mengatur tata aliran pekerjaan dan pelaksanaan kebijakan, yakni prosedur-prosedur kerja ukuran-ukuran dasar atau disebut Standart Operation Procedur (SOP).

Menurut Dessler (2003), mengemukakan bahwa jendela pensiun dini adalah sejenis penawaran dimana karyawan didorong untuk pensiun lebih awal. Insentifnya adalah tunjangan pensiun bebas dan barangkali ditambah dengan sebuah pembayaran tunai. Karyawan yang berhak mengambil program pensiun dini adalah karyawan yang memenuhi persyaratan tertentu, biasanya berumur 50 tahun atau lebih untuk ikut berpartisipasi dalam program pensiun dini yang ditawarkan oleh perusahaan. Normalnya dilakukan pada kisaran waktu 10 tahun lebih awal dari batas usia pensiun atau ketika usia anda berada pada usia 40-an dengan masa kerja 15-20 tahun

Pada dasarnya, hukum positif Indonesia tidak mengatur secara tegas mengenai pensiun dini. Undang-undang juga tidak membahas dan menentukan berapa usia minimum seseorang dapat mengajukan pensiun dini. Yang diatur dalam undang-undang soal pensiun adalah pengusaha dapat melakukan pemutusan hubungan kerja terhadap pekerja/buruh karena memasuki usia pensiun. Apabila pengusaha telah mengikutkan pekerja/buruh pada program pensiun yang iurannya dibayar penuh oleh pengusaha, maka pekerja/buruh tidak berhak mendapatkan uang pesangon, uang penghargaan masa kerja, tetapi tetap berhak atas uang penggantian hak. Hal ini tertuang dalam Pasal 167 ayat (1) UU Ketenagakerjaan.

Namun, setiap perusahaan diperbolehkan untuk menentukan dan membuat sendiri aturan mengenai pensiun dini dalam internal perusahaannya, Aturan ini dapat dibuat dan dituangkan dalam bentuk Perjanjian Kerja Bersama (PKB) maupun peraturan perusahaan. Jadi ketentuan mengenai pensiun dini dapat diatur lebih lanjut pada PKB maupun peraturan perusahaan. Telkom sebagai agen pemerintah yang berbentuk Persero harus membuat strategi untuk mencapai keuntungan, karena Telkom 
mempunyai tanggung jawab terhadap pemerintah sebagai stakeholders. Untuk menekan biaya perusahaan yang semakin membesar, maka pensiun dini muncul sebagai fenomena yang marak dilakukan BUMN, upaya ini untuk menekan beban aktiva keuangan Telkom. Karena bagaimanapun layanan yang diberikan harus baik, agar pelanggan tidak lari ke kompetitor lain.

Dalam melakukan penelitian ini, peneliti mengambil 4 indikator dalam teori Impelementasi Edward III yang meliputi komunikasi, sumber daya, disposisi, dan struktur organisasi.

Komunikasi. Dalam Implementasi kebijakan memerlukan komunikasi suatu program yang baik bagi para pelaksana. Hal ini menyangkut dari cara penyampaian informasi, kejelasan informasi dan konsistensi informasi yang disampaikan agar mencapai tujuan. Dalam konteks kebijakan program pensiun dini berjalan dengan baik. Kegiatan yang dilakukan program pensiun dini yaitu dengan cara sosialisasi,

Sumber daya manusia menuju efisiensi dan produktivitas di segala bidang. Perusahaan melakukan kemudahan pengakhiran hubungan kerja secara bijaksana dan mencoba membuat program yang menguntungkan kedua belah pihak. Berdasarkan penelitian dan wawancara kepada pihak Human Resource Center I, program ini ditujukan bagi pekerja yang tidak produktif, pekerja yang memiliki pendidikan rendah dan pekerja yang memiliki mutu personal pekerja yang rendah. Selain itu terdapat maksud implisit dari program hierarki perusahaan pada saat sebelum adanya program pensiun dini atas permintaan sendiri berada pada kondisi yang tidak ideal, baik dari segi formasi maupun golongan, sehingga dibutuhkan penyesuaian dalam segi sumber daya manusia.

Telkom sebagai agen pemerintah yang berbentuk Persero harus membuat strategi untuk mencapai keuntungan, karena Telkom mempunyai tanggung jawab terhadap pemerintah sebagai stakeholders. Untuk menekan biaya perusahaan yang semakin membesar, maka pensiun dini muncul sebagai fenomena yang marak dilakukan BUMN, upaya ini untuk menekan beban aktiva keuangan Telkom. Karena layanan yang diberikan harus baik, agar pelanggan tidak lari ke kompetitor lain. Kondisi teknologi saat ini sudah IT Based sehingga karyawan yang dibutuhkan semakin lama semakin sedikit, sehingga tidak lagi padat karya tetapi padat teknologi, dan beban yang dapat dihemat pengeluarannya adalah beban atau biaya Sumber daya manusia, karyawan yang tidak dapat mengikuti teknologi harus segera dipangkas. Kegiatan yang dilakukan dalam program pensiun dini di antaranya sosialisasi, pendaftaran, seleksi, konseling dan pembekalan, dan tahapannya di bagi atas dua bagian. Data yang peneliti peroleh, melalui wawancara dengan Bapak Suteki Human Resouce PT. Telkom Regional 1 menyatakan: "Pensiun dini ini tidak main-main, jadi Telkom sebagai perusahaan yang sangat memperhatikan kesejahteraan karyawan maupun mantan karyawannya, harus benarbenar diperhatikan agar tingkat kesejahteraan terus meningkat walaupun sudah tidak bekerja di Telkom lagi, karena pensiun dini ini tidak ada Masa Percobaan Pensiun, jadi mereka butuh sosialisasi, konseling dan pembekalan, agar mengetahui dunia pensiun yang akan disambut seperti apa".

Sumber Daya. Sumber daya memiliki peranan penting dalam implementasi kebijakan. Sumber daya manusia sangat berpengaruh dalam proses implementasi, karena tanpa adanya sumber daya manusia yang handal dalam bidangnya proses implementasi pelayanannya akan lama. Ada empat komponen dari sumber daya yaitu sumber daya manusia (staff), fasilitas (facility) yang dibutuhkan dalam pelaksanaan, wewenang (authorit) yang cukup guna melaksanakan tugas atau bertanggung jawab dan informasi (information) yang dibutuhkan guna pengambilan keputusan. Setelah tahapan sosialisasi kemudian Telkom membuka pendaftaran bagi karyawan yang berminat. 
Seleksi ini harus sesuai dengan ketetapan yang berlaku dan diputuskan dalam KR, dan harus segera disampaikan kepada para peserta paling lambat satu minggu sejak diluluskan permohonan pensiun dini. Persyaratan untuk pensiun dini tidak dapat langsung disetujui, karena perusahaan menilai karyawan yang lolos pensiun dini adalah benar-benar pegawai yang kompetensinya rendah, usia, dan beban kerjanya. Seperti yang diungkapkan oleh Bapak Wedy selaku Operational Manager Human Resources PT. Telkom Regional 1: "Syarat pensiun dini itu maksimal usia 50 tahun, yang paling diutamakan adalah kompetensinya dilihat dari NKI-nya, latar belakang pendidikannya mendukung tidak untuk pekerjaannya sekarang".

Setelah pegawai lulus seleksi maka akan dipanggil untuk konseling yang dilakukan oleh bagian HR Center. Mengenai hak-hak pegawai yang disampaikan dalam konseling diantaranya Tunjangan Hari Tua (THT), kompensasi yang di dapat, fasilitas kesehatan, dan tunjangan-tunjangan lainnya. Hal ini diungkapkan Bapak Suteki Human Resouce PT. Telkom Regional 1: "Kalau konseling kita memberitahukan seluruh hak-hak yang diterima si calon, lengkap beserta hitungan-hitungannya. Dan hal ini tertuang dalam keputusan direksi, jadi wajib kita laksanakan, yang memberikan konseling itu bagian SDM unit masing-masing dan yang pasti tidak melibatkan psikolog atau institusi lainnya, murni internal Telkom saja". Setelah konseling, kegiatan yang dilakukan Telkom adalah pembekalan, dan khusus untuk karyawan yang telah lolos tahap konseling saja yang dapat mengikuti tahapan ini. Kegiatan pembekalan sangat dibutuhkan oleh para karyawan yang mengajukan pensiun dini, agar mempunyai gambaran yang selanjutnya diambil, apakah ingin usaha atau justru untuk berfoya-foya. Tahapan paling penting adalah tahapan pembekalan, harus dipersiapkan sebaik mungkin, agar tidak menyesal dikemudian hari telah melakukan pensiun dini. Selama ini kegiatan pembekalan sudah efektif dan telah dijalankan dengan baik dan terencana. Data mengenai kegiatan pembekalan yang Telkom lakukan diungkapkan oleh Bapak Wedy Operational Manager Human Resources PT. Telkom Regional 1melalui hasil wawancara sebagai berikut: "Pembekalan itu biasanya berupa pengarahan dan ceramah, pembekalan juga dapat dilakukan dengan mengunjungi tempat-tempat bisnis agar dapat dilihat pengelolaannya sehingga memunculkan motivasi".

Kegiatan-kegiatan kunjungan ke tempat-tempat tersebut sebenarnya adalah untuk memberikan contoh nyata dunia usaha yang dapat digeluti oleh para pensiunan, agar dapat segera diaplikasikan.

Disposisi. Disposisi atau sikap pelaksana adalah faktor yang penting dalam pendekatan mengenai pelaksanaan atau kebijakan publik. Jika pelaksana kebijakan ingin berjalan efektif maka aparatur tidak hanya harus mengetahui apa yang harus dilakukan tetapi memiliki kemampuan untuk melakukannya. Dalam penelitian yang didapat, sikap pelaksanaan dalam implementasi cukup baik. Hal ini disampaikan oleh Bapak Sukoco selaku Human Resouce service PT. Telkom Regional 1 yaitu: "Sejauh ini Telkom menilai sikap dan perilaku kerja para pelaksana pensiun dini, tidak ada penyimpangan karena Telkom selalu memberikan yang terbaik untuk para karyawannya sehingga implikasi yang ada pun pastinya karyawan akan memberikan sumbangsih terbaiknya untuk setiap program yang Telkom miliki dan galakkan, termasuk pensiun dini".

Kalaupun terjadi penyimpangan akan segera ditindak lanjuti perusahaan karena pensiun dini ini sangat penting untuk keberlangsungan operasional perusahaan ke depan, dengan pensiun dini akan memudahkan Telkom merestrukturisasi organisasinya.

Struktur Birokrasi. Struktur birokrasi adalah tata aliran kerja birokrasi yang mengatur tata aliran pekerjaan dan pelaksanaan kebijakan, yakni prosedur-prosedur kerja ukuran-ukuran dasar atau disebut Standart Operational Procedure (SOP). Seiring 
dengan kegiatan pensiun dini maka akan terjadi perubahan dalam struktur perusahaan karena beban pekerjaan yang dihadapi tetap sedangkan SDM yang dimiliki tidak sebanyak sebelum pensiun dini, namun Telkom mensiasati ini dengan merekrut tenagatenaga baru yang mempunyai kualifikasi yang dibutuhkan Telkom, selain itu juga untuk regenerasi karyawan, karena karyawan dengan usia yang sudah tidak produktif lagi cenderung mengalami kesulitan dalam menerima kemajuan teknologi sedangkan Telkom dalam pelaksanaan pekerjaannya sudah berbasis digital computerised.

Struktur birokrasi perusahaan cukup efektif dan efisien, karena jarang terjadi permasalahan dalam Telkom yang disebabkan oleh struktur perusahaan, pensiun dini juga sebagai pertimbangan dalam mendesain ulang struktur perusahaan Telkom. pensiun dini ini dilaksanakan dan dibantu oleh semua departemen, jadi tidak ada masalah dengan struktur perusahaan sekarang, jika ada bisa langsung masuk agenda rapat luar biasa Telkom.

\section{SIMPULAN}

Berdasarkan hasil penelitian dan pembahasan, peneliti dapat menyimpulkan bahwa implementasi kebijakan program pensiun dini di PT. Telkom belum maksimal dalam menjalankan program pensiun dini, hal tersebut dapat dilihat dari tahap-tahap yang dilalui dalam implementasi kebijakan program pensiun dini di PT. Telkom: (1) Komunikasi, proses penyampaian informasi yang dilakukan oleh Telkom berjalan dengan baik bahwa sosialisasi itu untuk memberikan pemahaman menyeluruh mengenai pensiun dini. Sosialisasi yang dilakukan diantaranya melalui teleconference, intranet, dan indonet yang berisi penjelasan mengenai pension dini, syarat-syarat, dan juga kelengkapan data; (2) Sumber Daya, seluruh pihak (staf) dalam manajemen Telkom, diharapkan dan dituntut partisipasinya, tidak hanya departemen SDM saja yang bergerak untuk mensosialisasikan namun seluruh departemen maupun non-departemen yang ada di Telkom; (3) Disposisi (Sikap Pelaksana), sejauh ini Telkom menilai sikap dan perilaku kerja para pelaksana pensiun dini, tidak ada penyimpangan, karena Telkom selalu memberikan yang terbaik untuk para karyawannya sehingga implikasi yang ada pun pastinya karyawan akan memberikan sumbang sih terbaiknya untuk setiap program yang Telkom miliki termasuk pensiun dini; (4) Struktur Birokrasi perusahaan cukup baik, karena jarang terjadi permasalahan dalam Telkom yang disebabkan oleh struktur perusahaan, pensiun dini ini juga sebagai pertimbangan dalam mendesain ulang struktur perusahaan Telkom. Pengaruh struktur birokrasi terhadap implementasi kebijakan dapat dilihat dari Standard Operating Procedures (SOP) yang berkembang terhadap sumber- sumber dari para pelaksana serta keinginan untuk keseragaman.

\section{DAFTAR PUSTAKA}

Atika, T.A, dan Usman T., (2014). Prosedur Penerbitan Surat Keputusan Pensiun Pegawai Negeri Sipil pada Badan Kepegawaian Daerah Deli Serdang, JPPUMA: Jurnal Ilmu Pemerintahan dan Sosial Politik UMA (Journal of Governance and Political UMA), 2 (1): 18-30

Dessler, G. (2009). Manajemen Sumber Daya Manusia (Edisi Kesepuluh Jilid 2. Jakarta: Indeks

Harsono, H. (2002). Implementasi Kebijakan dan Politik. Bandung: PT. Mutiara Sumber Widya

Hasibuan, M.S.P. (2012). Manajemen Sumber Daya Manusia. Jakarta: PT. Bumi Aksara

Sugiyono, (2015). Metode Penelitian Kuantitatif, Kualitatif dan R\&D. Bandung: Alfabeta.

Tangkilisan. (2003). Konsep Kebijakan Publik. Penerbit PT Gramedia Pustaka Utama.

Undang-undang Nomor 11 Tahun 1992 Tentang Dana Pensiun

Undang-undang Nomor 13 Tahun 2003 Tentang Ketenagakerjaan

Widodo, J. (2010). Analisis Kebijakan Publik. Malang: Bayumedia. 